\title{
Integrated Farming System and Human Resource Planning and Management for Livelihood Security and Capacity Building of Tribal farming Community in District Dehradun, India
}

\author{
Singh HN*, Raghav M, Singh B, Kuswaha KPS, Singh YV, Singh J, Ruhela A and Pal VK \\ College of Agriculture, GBPUAT, India
}

Submission: May 21, 2018, Published: July 09, 2018

"Corresponding author: Singh HN, College of Agriculture, GBPUAT, Pantnagar-263 145 Udhamsingh Nagar, India, Email: hns_eco@rediffmail.com

Keywords: Tribes population; Fruit crops; Farmer-beneficaries; Poultry production; Farmers' fields; Chakrata blocks; Eggs; Rabi season; National security.

\section{Short Communication}

Scheduled tribes in India traditionally remained socially, culturally isolated and economically backward. Process of their integration with rest of the population remained slow. There are about 3 lakh tribes residing in Uttarakhand which constitutes $3 \%$ to total population of state. Community Development Blocks Kalsi and Chakrata, district Dehradun were identified by the Planning Commission, Govt. of India where tribes population were about 64.27 and $61.84 \%$ to total population, respectively. The main tribes of the area are Tharus, Jaunsaris, Buxas, Bhotiyas and Rajis.

The objective of project is the socioeconomic upliftment of tribes through agricultural development by creating awareness by imparting trainings to the beneficiaries of the potential benefits of improved technologies. Apart of it, provided some critical inputs for their on-farm demonstration and large-scale adoption. Area of technologies are poultry production, hybrid rice cultivation, off-season vegetables, mushroom production, short duration pulses, small ruminant, short duration fruit crops, vermi composting \& uses of bio-fertilizers. Currently project activities are being continued in 26 villages in which 16 villages in Kalsi and 10 villages in Chakratabolcks. A total of 1810 farm families already been covered under different activities of the project.

Capacity building programs: Farmer-beneficaries of selected villages were imparted trainings for farm-level management practices of initiated technologies. In addition to it, creation of knowledge and awareness among the farmers, supply of farm inputs to the beneficiaries were also ensured for adoption of income enhancing interventions on their farms. To this end, a total of 4328 farmer-benificaries have been benifitted by capacity building programs on different aspects in last two years 2013-14.Among total participants about 55\% male and 45\% female farmers participated in the capacity building programs of improved interventions. In view of women empowerment and address the issues of gender due consideration was also given to include substantial number of female-farmers in supply of input (41\%).

Critical farm input supplied: Similarly, a large number ofbenificariescomprising male \& female (1062) were supplied farm inputs to conduct demonstration on their farms. The critical inputs were supplied to the farmers as per requirement of different activities to judge the performance of technologies on their farms. The listed activities under different sub-component have already been initiated and continued in the selected villages of both the blocks.

Farmers-scientist interactions: Farmer's scientist interactions were organized by different sub components with a view to have the feedback of beneficiaries in response to adoption of varios technologies. A total of 1906 benificiaries participated in the interaction. Scientists' appropreitly responded the querries of beneficaries related to on-going process of adoption of technologies. 


\section{Achievements}

The field performance of poultry production, hybrid rice cultivation, off-season vegetables, short-duration pulses, and mushroom production were excellent and delivered exciting results in terms of producing output, generation of income and employment on farmers' fields.

In poultry production component of the project, 2250 and 1520 numbers of day old chicks along with wire mesh, feed, medicine etc. were distributed among the beneficiaries of selected villages in Kalsi and Chakrata blocks, respectively after imparting rigorous training to them. After mortality of chicks the remaining balance stock of birds were 2084 and 1391 numbers with the tribal beneficiaries in Kalsi and Chakrata blocks, respectively.

Beneficiaries of poultry component sold about 630 and 450 broilers in the market for cash purposes on a value of Rs. 2.80 lacs and Rs. 2.04 lacs in Kalsi and Chakrata blocks, respectively. The farm-get price of broiler ranged from Rs. 450 to 600/ per broiler. Whereas, about 630 broilers valued Rs. 2.83 lacs have consumed by the family-members of beneficiaries. To this end about 1.75 lacs eggs produced on beneficiaries farm valued Rs. 8.80 lacs (Rs. 5/egg).A sum of total Rs.16.47 lacs income generated from sale of broilers and eggs. A substantial number of layers (1470) maintaining on beneficiaries' farms for egg laying. Therefore, it can be mentioned undoubtedly that 'poultry production' is an extremely suitable and favorable technology not only for generating income and employment of tribal farm families, but also ensured food and nutritional security.

The field performance of hybrid rice PA 6444 was excellent across the villages due to better management practices followed by the beneficiaries after intensive training/education to them and favorable rainfall distribution pattern in rice cropping season. The average yield of hybrid and non-hybrid rice on farmers field were 70 and 38qtls/ha, respectively. Yield range of hybrid rice on farmers field was 66-76qtl/ha whereas, in case of non-hybrid rice it ranged from 32 to $47 \mathrm{qtls} / \mathrm{ha}$. The average incremental yield from hybrid rice was 32 qtls /ha on farmers field over the non-hybrid rice varieties.

The additional rice produced by beneficiary farmers is as 436qtls which valued Rs.6.54 lacs on current market price by adopting hybrid rice technology in project villages. Additional income of Rs. 6.54 lacs generated from the project activity under hybrid rice component. The additional rice gain occurs due to adoption of hybrid rice technology which may be effective to strengthen the food security \& income enhancement issues of tribal farm families in project areas which ultimately led to food security.

Improved wheat variety PBW 226 also performed in an exclusive manner on farmers' field as they were previously growing old and local wheat cultivar in rabi season. The average yield of PBW 226 on farmers filed was 25.0 qtls./ha which is 3.0qtl/ha higher than the average yield ofold/local varieties.In rabi season, a total of 325 tts additional wheat was produced in project villages through adoption of improved which technology on farmers filed.The market value of wheat grain and straw together was Rs. 6.18 lacs. However, rice-wheat is prevailing and most popular cropping system on the farmers' field in the project villages. Therefore, a total income generated from this system was Rs. 12.72 lacs though adoption of improved hybrid rice and wheat technologies.

Demonstrated off-season vegetable technology performed in an exclusive manner through which beneficiaries were improving their income and employment opportunity. A total of 219 beneficiaries were provided improved seed of vegetables such as tomato, capsicum, cabbage, French bean, okra and bitter gourd along with fertilizers and agro-chemicals in the project villages. Out of 219 beneficiaries, 114 beneficiaries were from selected villages of Kalsi block and produced about 597qtls. vegetables on their farms. Whereas, remaining 105 beneficiaries belong to Chakrata block and produced 560 qtls vegetables.

The net value of vegetables produced in Kalsi block was Rs. 10.50 lacs, whereas the corresponding value for Chakrata block was Rs.8.70 lacs. Therefore, an attractive amount of total income of Rs.19.20 lacs generated from the adoption of offseason vegetable technology on farmers field. The average annual income generated from off-season vegetable production were Rs.50201/- and Rs.117890/- per beneficiary in Kalsi and Chakrata blocks, respectively. Therefore, beneficiaries involved in off-season vegetable production are now improving their income and also utilizing employment opportunities which arise through adoption of this component on their farm. In addition to vegetables sold in the market, family members of beneficiaries also consumed a substantial amount of vegetables which ultimately enhances nutritional status of their family members.

In short duration pulses component, total production of pulses comprising lobia and moong bean was $48.20 \mathrm{qtl}$ on farmers' field in both the blocks and net income generated from this component is Rs. 3.86 lacs. However, the net income generation by adopting lobia cultivation is Rs. 2.16 lacs followed by moong bean cultivation Rs. 1.70 lacs in the project villages. Pulses are essential component of the diet of tribal farmers, therefore, through introduction and diffusion of short duration pulses varieties pulses requirement can be met out.

Under mushroom production technology, farm inputs supplied to 15 beneficiaries in the project villages. Total production of mushroom (button) was $1147.5 \mathrm{~kg}$ and the average yield was $76.50 \mathrm{~kg} /$ beneficiary farms. In initial stage the estimated net gain from mushroom production was Rs.1214/ beneficiary(Figure 1). 


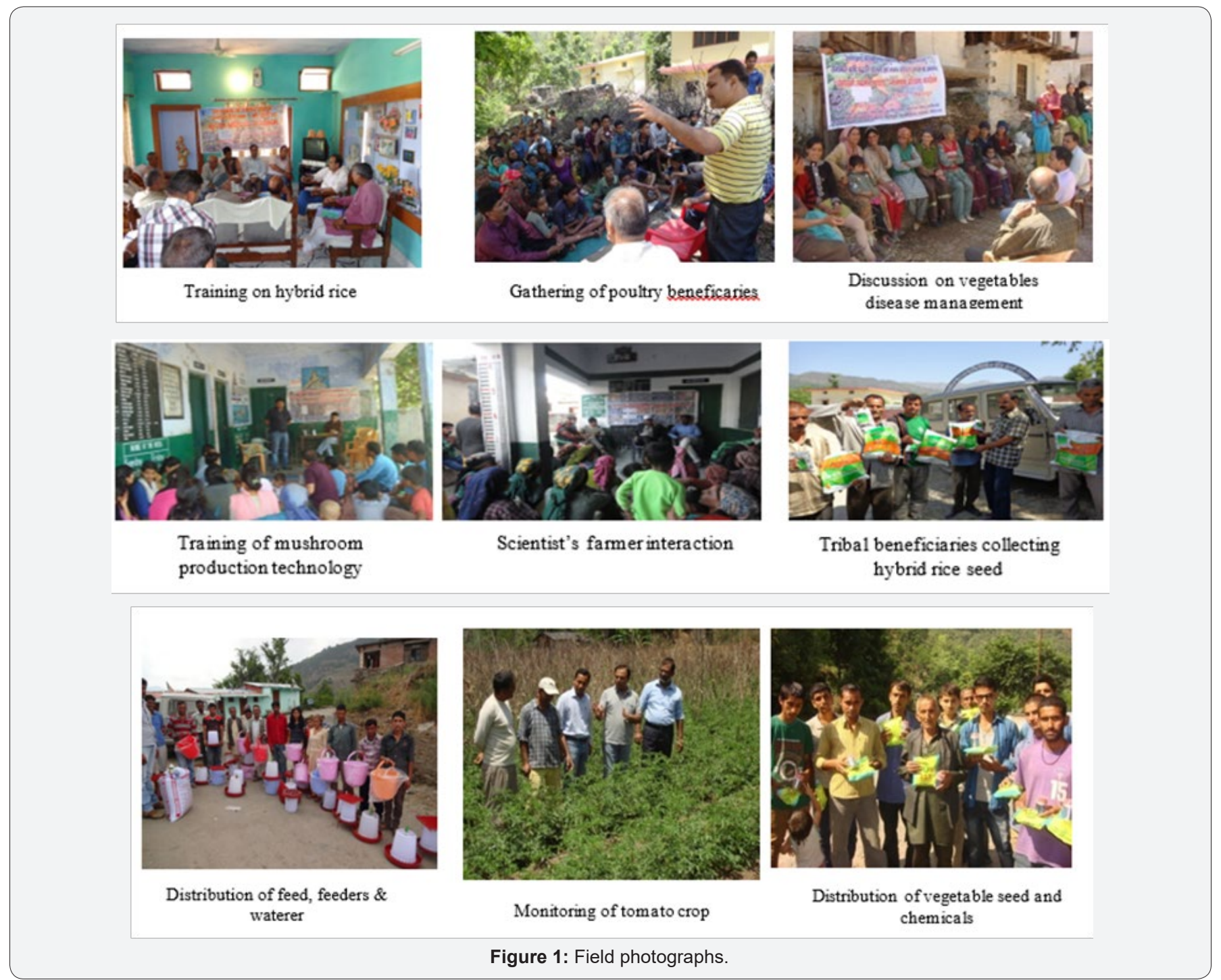

All the tribal-farmer beneficiaries related to the project activities seems encouraged and satisfied from the efforts of university scientists after implementing income augmenting/ generating technologies/interventions on their farms.All beneficiaries have also appreciably realized the impact of improved farm technologies implemented through this project which lead towards food and national security of tribal farming community, addition to income enhancement.

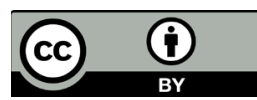

This work is licensed under Creative Commons Attribution 4.0 License DOI: 10.19080/ARTOAJ.2018.17.556010

\section{Your next submission with Juniper Publishers will reach you the below assets}

- Quality Editorial service

- Swift Peer Review

- Reprints availability

- E-prints Service

- Manuscript Podcast for convenient understanding

- Global attainment for your research

- Manuscript accessibility in different formats ( Pdf, E-pub, Full Text, Audio)

- Unceasing customer service

Track the below URL for one-step submission https://juniperpublishers.com/online-submission.php 